\title{
External Insights to Boost Internal R\&D Efforts of the Fish and Seafood Export Processing Industry in Sri Lanka
}

\section{D.A.M. De Silva ${ }^{1}$ and Trond Bjorndal ${ }^{2}$}

${ }^{1}$ Department of Agribusiness Management, Faculty of Agricultural Sciences, Sabaragamuwa University of Sri Lanka, P.O. Box 02, Belihuloya, Sri Lanka.desilva.achini@yahoo.co.uk

${ }^{2}$ Centre for the Economics and Management of Aquatic Resources(CEMARE), Portsmouth Business School, University of Portsmouth, St. George's Building, 141, High Street, Portsmouth, Po1 2HY, United Kingdom.Trond.Bjorndal@port.ac.uk

\begin{abstract}
This research is focused on the fish and seafood export industry of Sri Lanka, considering its importance to the country's economy. The objectives of the study are to investigate the nature of open innovation practices among fish and seafood exporters in Sri Lanka and to find out the role of open innovation on product and process development, market identification, market expansion, brand image, quality control, labelling and certification, sales promotion and advertising, and the sustainability of the resource base. The empirical study is based on the data obtained from 26 EU approved fish and seafood processing establishments. A structured questionnaire followed by interviews with CEOs, R\&D heads and quality controllers were the principal data collection tools. Hansen and Birkinshaw's capability measure is used to measure the firm's level on idea generation, conversion and diffusion. Processing firms were divided into three groups; idea-rich/poor, conversion rich/poor and diffusion rich/poor. Hypothesis testing proved the positive relationship between firm performance and open innovation practices of the firms. Results reveal that firms are idea rich, conversion and diffusion moderate. Moreover, the study has identified open innovation partners, the nature of their support and the open innovation process of the fish and seafood export processors.
\end{abstract}

Keywords: open innovation, fish and seafood processing, Sri Lanka

\section{Introduction}

The most critical point that producers and marketers have to understand is "selling the way your customer wants to buy, not the way you like to sell" (Grehalva, 2004). Especially when you are catering to geographically and culturally distinct markets, the above mentioned considerations have extra ordinary importance. Thus, knowing the customers actual buying behaviour is 
important. Generally, customers do not buy only products, they buy solutions or benefits. Therefore, producers who think in terms of the benefits are mostly customer oriented.

One of the fast growing food industries in the world is the seafood industry. Customers today have become more experienced, educated and sophisticated about their fish and seafood selection due to which there has been a significant change in consumers' tastes. Fish and seafood marketers have to invest more in order to compete with other protein foods like meat, poultry, and vegetables. Today, fish and seafood products represent a significant opportunity to broaden sales for supermarkets that become a point of destination for consumers who are demanding a wider selection of top-quality items at competitive prices. In 2008, exports of fish and fishery products reached record value of 102 billion US\$ (FAO, 2010). Over half of this trade originated from developing nations of Asia, Africa and Latin America and most of the products were destined for the markets in the EU, Japan and the USA.

The current research is emphasising the fish and seafood export industry of Sri Lanka, considering its importance to the country's economy. The fish and seafood export industry in Sri Lanka has emerged as a dynamic export oriented sector providing considerable foreign exchange to the country. The industry is recognised as a sector with high potential to earn foreign exchange by exporting both marine and fresh water fish and fishery products to the international market. The value of exports has increased from $103 \mathrm{~m}$ US\$ in 2005 to $202 \mathrm{~m}$ US\$ in 2010, indicating an average annual growth of $15 \%$ (Ministry of Fisheries and Aquatic Resources, 2010). The country's main export destinations are the EU, Japan and the USA. In Sri Lanka, more than 120 exporters, including 26 EU approved export processing establishments, export fish and seafood products to international markets.

In the case of research and development (R\&D), even the sharpest leading edge companies can no longer survive on their own R\&D efforts, but they must open up their networks and collaborate with others (OECD, 2007). Maintaining R\&D labs and staff becomes a big burden to both large and small scale companies, and especially the case of developing nations is critical. Different countries have different levels of R\&D, many could boost their merely pumping up R\&D and it can wide the finer print about education, business environments, innovation culture, infrastructure and institutional support. Moreover, Sri Lanka was ranked 54th in the global innovation index (Nationmaster, 2008).

The competitive advantages and the differences they create in firm performances are often strongly related to the resources of firms and management (Hall, 2010). In the current landscape, the resources, capabilities and core competencies in the firm's internal organisation are likely to have positive 
influence on its performance when they are combined with complementary resources in the external environment (Hall, 2010). Crowed sourcing or open innovation make available for new resource avenues of different origins that can be successfully employed for organisational value creation. Open innovation platforms provide various opportunities to firms such as access to the ideas and technologies that the firms cannot generate by themselves with licensing and spin-off benefits.

An important source of external resources are (loyal) customers who provide critical insights on how to improve the product, whereas connecting to motivated customers promises the capture of emergent opportunities (Hall, 2010). Moreover, creative individuals and communities can be a very important source of innovation, especially joint ventures with university and research institutions may lead to create fruitful innovations. High levels of literacy rate (94.2), educated and skilful youth with innovative skills (literacy rate 97 for males and 99 for females between 15-24 years of age) provide a better external environment for the crowed sourcing in Sri Lanka (UNICEF, 2010).

Present study aimed to investigate the nature of open innovation/coinnovation practices of fish and seafood export processors in Sri Lanka. Specific objectives of the study focused to identify the role of open innovation in the export marketing and identify the contribution of open innovation on firm performance. The paper is organised into three main sections: the first section deals with the back ground information and conceptual frame work, the second section discusses the research methodology of the study and the last section consists of the findings, discussion and of conclusion.

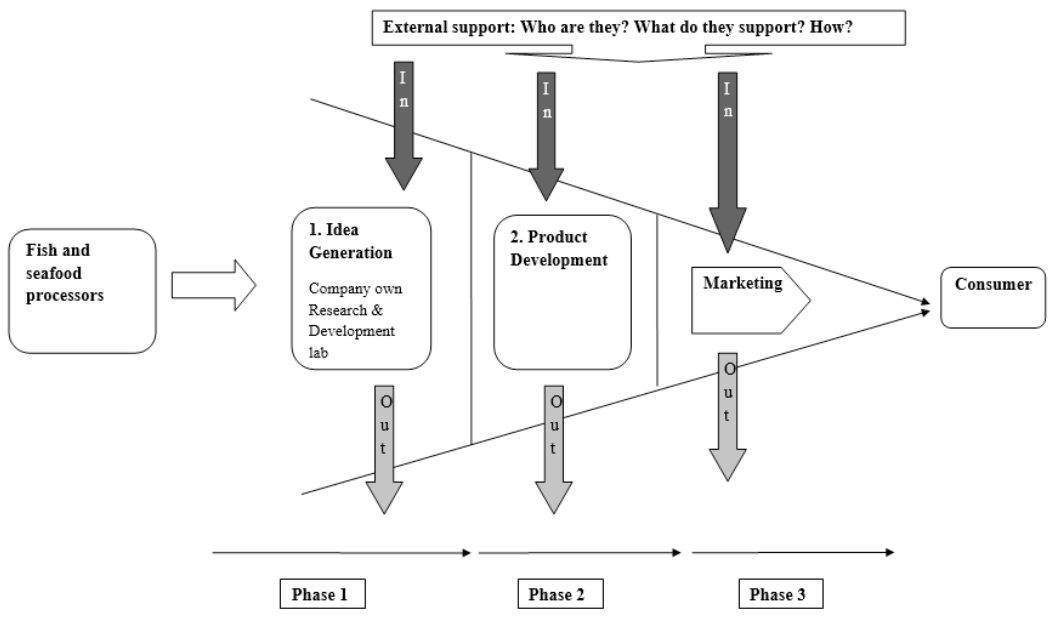

Figure 01: Conceptual frame work 
Conventional wisdom or the famous closed innovation model considered the occurrence of innovations in closed environments often performed by individuals, scientists or employees. However, open innovation explains that firms can and should use external and internal ideas, and external paths to market when firms need to advance their technology (Cesbrough, 2003). Thus, the open innovation is the baseline for the conceptual framework of the study. The conceptual frame work begins in the firm and ends in the market where consumers receive the product or bundle of attributes. As per the open innovation landscape, there are three phases involved between the firms and consumers. These are idea generation; product development and marketing (see Figure 1). In every stage it is important to study the ideas and resources involved how they are involved, etc. As indicated in Figure 1 the ideas and resources could generate from fish and seafood processors, and from external support. Thus, it is important to identify and measure the external support involved, how they are involved and what they support in every phase of the conceptual frame work. Further, the conceptual framework explains the draining of ideas and resources in all phases as spin offs, franchising, partnerships, etc. Conceptual framework was based on the ideas of globalised value chains, especially where the fish and seafood products belong. The open innovation model believes that a company's value chain no longer exists fully within the company's boundaries. Ideas, individuals and products flow across company boundaries, to and from other companies, universities and countries (Duke, 2004).

\section{Methodology}

The research is based on fish and seafood processing firms in Sri Lanka, and the study population consisted of 103 registered fish and seafood export processing firms. Sampling technique was purposive and the research sample composed of $26 \mathrm{EU}$ approved establishments. The EU approved fish and seafood processing establishments were chosen for the first empirical test of this study because all of these firms were catering to the EU, Japan and the USA markets and not local markets. Data were collected in the 2011 and the study was heavily based on primary data. The main data collection tool was structured questionnaire followed by in-depth interviews with selected industry statkeholders. The questionnaire was composed of three main sections: the first part was designed to collect the information of the firm's general information such as product categories, turnover, markets, certification and traceability, and marketing system.

The second part was designed to collect data on social networks and crowed sourcing experiences. In this part of the questionnaire the Hansen and Birkinshaw's (2007) capability measure was used to measure the firm's level on idea generation, conversion and diffusion. Hansen and Birkinshaw's 
measure views innovation as a value chain where managers have to perform six critical tasks, such as internal sourcing, cross-unit sourcing, external sourcing, selection, development, and company wide spread of the idea. Based on this method firms could be divided into three groups, namely idea-rich or poor company, conversion rich or poor company and diffusion rich or poor company. Moreover, the firms open innovation experiences were measured by using 13 statements of Hansen and Birkinshaw's measure. In addition, nine other statements on open innovation concepts and their response on sustainability were measured.

The final part of the questionnaire was prepared to collect information on the firm's cooperate partners, their destinations and roles. Moreover, follow up interviews were scheduled with the CEOs, managing directors and chief quality control officers of the selected firms. The main aim of conducting personal interviews was to obtain detailed information on the social networks, the role of the social networks and most of all to gather information on the interviewee's experience in the open innovation practices. The theoretical arguments lead towards the development of the following hypotheses. The firm's performance was measured using two indicators; the number of products introduced during the last three years and the number of markets catered to during last three years.

\section{Results and Discussion}

The baseline information of fish and seafood processing establishments were the first consideration and the background would support identify the ground situation. Twenty six EU approved establishments were purposely selected, of which 23 were owned by Sri Lankans and the key positions were also held by the country's nationals. Three establishments were operating as joint ventures where foreigners collaborate with Sri Lankans. Of the sample 96\% of the establishments were operate as limited liability companies. Place of head quarters for majority (87\%) was Sri Lanka while rest has selected United Kingdom and Japan for their head quarters.

$\mathrm{R} \& \mathrm{D}$ department was not presented in any organizational structure while $78 \%$ of the companies have own R\&D employees attached to the quality control or production departments. Majority of the firms $(88 \%)$ have their own R\&D budget. Especially the amount of R\&D expenditure varied from $5-10 \%$ where $46 \%$ spend $5 \%$ from their sale expenditure and $42 \%$ spend $10 \%$ for R\&D activities. Eighty eight percent of the companies have full time R\&D employee and the person act as an innovation leader to the firm.

Field survey has identified $42 \%$ of the companies have own innovative products while $82 \%$ has products new to the firm but not to the global fish and seafood market. Interestingly, considerable number of firms $(68 \%)$ 
manage own product or process development strategies. Study has identified various institutions as social network partners for the fish and seafood export processors. Social networks composed of both governmental and non governmental institutions, i.e. universities, research institutions, industry experts and consultants, competitors, raw material suppliers, retailers and retail chains, wholesalers and traders, consumers, export development board, Ministry of Fisheries, advertising and sales promotion, Non Governmental Organizations

Common marketing strategy was to supply foreign retails and retail chains while $22 \%$ of the firms using their own brand name as well as own promotional campaign. Export composition of the processing companies composed of tuna (yellow fin, skipjack and big eye), swordfish and shrimp were common in the export basket. The majority of the processors were dealing with tuna and swordfish with the exception of two companies. Export composition based on several product categories, such as fresh, semi processed and ready to cook forms. Majority $(50 \%)$ of the processors were now producing ready to eat forms which brings better returns.

Firms' commitment on international market regulations, especially on certification systems, is presented in figure 2 . All respondents of the sample were strengthened with HACCP, EU and traceability certifications. Whereas, majority of the respondents maintain British Retail Consortium (BRC), US Food and Drug Administration (FDA), and ISO series (9000, 14000 and 22000).

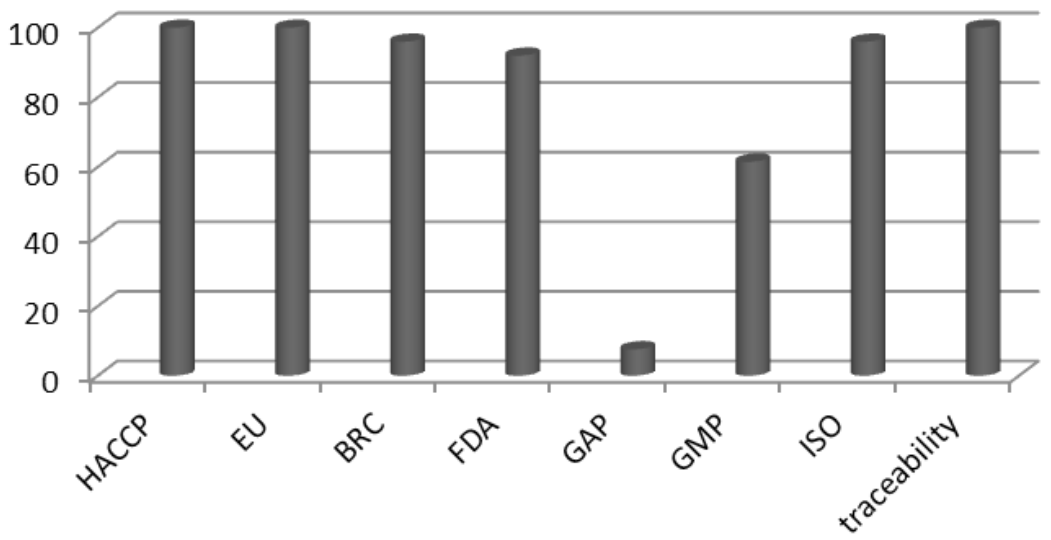

Figure 02: Commitment on international market regulations 


\section{External crowds, nature of their support and process of collaboration}

\section{Phase one - Idea generation}

The majority (93\%) of the export processors were directly linked with foreign retail chains (ASDA, Tesco, Morison's, Waitrose, Aldi, Marks and Spencer, Wal-Mart, etc.). Retail chains provide regular market information such as regulatory requirements (certification, health and safety issues, nutritional and dietary considerations, tariff and taxes, legal and policy matters), consumer demands (species preferences, product types, processing methods, packaging, organic and environmental demands, seasonal demands, price concerns), society and consumer concerns on sustainability, labour and animal rights, and market trends. Moreover, importers, traders and wholesalers were also a reliable source of market information and help to shape the process.

Local research institutions (ITI-Industrial technology Institute), research labs and universities were facilitating through transfer of technologies, product and process ideas, product upgrading and troubleshooting, contract research and development, supplying standards and manuals, and market research. Long established export processors were maintaining strong links with university academics, researchers and employ interns regularly. Social networks with foreign and local entrepreneurs, start-up companies and SMEs were providing great help in the process of idea generation. Competitors, both local and foreign, are always in a battle but the competitive spirit is useful in providing market trends, ideas and regulatory requirements. Only few firms were able to manage strong ties with their foreign consumers, while others have shown poor customer relations. Majority of the sample (78\%) totally depends on their buyer's requirements as they export directly to retail chains and individual buyers in the international market. Manufacturing process totally depends on buyer specific requirements. Consumer links are helpful in getting valuable ideas on preferred species, product types, product design, packaging, processing methods, seasonal demands and socio-cultural requirements.

\section{Phase two - Product development}

Firms holding sole responsibility of the product development stage accomplish their tasks with external support. All export processors were maintaining healthy relationships with governmental organisations which facilitate the export industry. Principally, the quality control division of the Ministry of Fisheries and Aquatic Resources provides legal and policy strength to the export processors. Thus, it helps to manage stringent quality control procedures and their regular inspection helps to secure firm position in the international market.

Firms ofthe study sample were maintaining a traceability system (trace back to the fishing point/ fishing vessel, etc.), HACCP procedures, ISO 
9000/14000/22000 series, BRC (British Retail Consortium), US Food and Drug Administration requirements, GAP (Global Aquaculture Practices) and sustainability labelling (Friend of the Sea). Export Development Board, Ministry of Trade and Commerce, Department of Customs, Board of Investment were the leading government institutions facilitating the operation. Firms maintaining closer links with universities and research institutions were enjoying a wider product range and catering to a large number of market segments compared to others with weaker links.

\section{Phase three - Marketing}

Value chain members provide great help in this stage, especially in catering to the existing market or entering into new markets. Raw material suppliers, including own vessels and crews were helping to manage and maintain the quality control procedures. This step is utmost important when dealing with highly perishable products. Moreover, outbound logistics such as air freight, shipping, transport (local and foreign), insurance, etc., were facilitating the process with timely supply of products to global markets. The majority depend on retail chains in the UK, Germany, France, Switzerland, Italy, the USA and Japan, and they were handling the entire marketing process without intervention of the local processors. Moreover, trade exhibitions and advertising campaigns help to identify new consumers, buyers, market trends and regulatory background of the international markets. The Export Development Board was facilitating in organising and participation in international trade fairs and supporting in identifying foreign buyers.

\section{Rating open innovation in fish and seafood value chains}

The present study aims to identify the relationship between the firm's performance and the firm's engagement with external sourcing of ideas or open innovation. Table 01 presents the results of the analysis of in-house idea generation. Laursen and Salter (2006) have identified the relationship between the openness of UK firm's external search strategies and their innovative performance and results proved a positive relationship. Export processing firms were rich in ideas and employees in different levels as well as divisions of the organisation bring lots of bright ideas on product and process development. Organization culture encourages its employee's innovative behaviour and facilitates for testing.

Table 01: Measurement of In-house idea generation

\begin{tabular}{lcc}
\hline \multicolumn{1}{c}{ Statement } & Mean & Std. Deviation \\
\hline $\begin{array}{l}\text { 1. Our culture makes it hard for people to put } \\
\text { forward novel ideas }\end{array}$ & 2.15 & 0.54 \\
$\begin{array}{l}\text { 2. People in our company come up with lots of } \\
\text { good ideas on their own }\end{array}$ & 4.03 & 0.19 \\
\hline
\end{tabular}


Table 02 indicates the findings of the cross-pollination of business ideas among different departments, divisions or units. The results revealed that most of the innovative projects of the companies were the result of team work rather than individuals. Moreover, respondents agreed on the statement on internal collaboration of projects and members of all departments or divisions work together to achieve desired tasks. Results of Table 01 and 2 highlighted that companies were idea rich and positive on internal collaboration.

Table 02: Measurement of Cross-pollination among businesses

\begin{tabular}{lcc}
\hline \multicolumn{1}{c}{ Statement } & Mean & Std. Deviation \\
\hline $\begin{array}{l}\text { 3. Few of our innovation projects involve team } \\
\text { members from different units or subsidiaries }\end{array}$ & 2.38 & 0.80 \\
$\begin{array}{l}\text { 4. Typically, our people collaborate on projects } \\
\text { internally, across units, businesses or subsidiaries }\end{array}$ & 4.00 & 0.00 \\
\hline
\end{tabular}

Table 03 brings the results of the external sourcing of ideas on product and process development, technological know-how, market information, etc. Firms have shown positive attitudes towards the external sourcing of ideas and they regretted the concept of "not invent here". Especially, they are catering to geographically distinct markets and ready to accept the buyers and consumers views on product and process development. Previous studies support this argument. Sarka et al., (2008) analysed the impact of the open innovation strategies employed in the food industry. Moreover, a literature survey highlighted that open innovation strategies come in a variety of forms and meet with a wide variety of outcomes including improved market capabilities, economic returns, strengthened R\&D efforts, etc.

Table 03: Measurement of external sourcing of ideas

\begin{tabular}{lcc}
\hline \multicolumn{1}{c}{ Statement } & Mean & Std. Deviation \\
\hline $\begin{array}{l}\text { 5. Lots of good ideas for new products and } \\
\text { businesses come from outside the company }\end{array}$ & 4.23 & 0.42 \\
$\begin{array}{l}\text { 6. Our people often regret a "not invent here" } \\
\text { attitude - ideas from outside are considered as } \\
\text { valuable as those invented within }\end{array}$ & 4.00 & 0.00 \\
\hline
\end{tabular}

Results of the measurement of idea or product concept selection showing positive results (see Table 04). They were neutral on risk taking attitude and limited or no-availability of investment finance made it hard to put forward novel ideas into operation. Processing firms were figuring positive attitudes towards investing in new product or process concepts if available resources permit them to do so. 
Table 04: Measurement of idea/product selection

\begin{tabular}{lcc}
\hline \multicolumn{1}{c}{ Statement } & Mean & Std. Deviation \\
\hline $\begin{array}{l}\text { 7. We have tough rules for investment in new } \\
\text { products-it's often too hard to get ideas funded }\end{array}$ & 2.53 & 0.58 \\
$\begin{array}{l}\text { 8. We have a risk-taking attitude toward } \\
\text { investing in novel ideas }\end{array}$ & 3.34 & 0.84 \\
\hline
\end{tabular}

Results of the top management's views on product development and internal collaboration on that process are presented in Table 04 . The respondents agreed that new product development projects were not completed within time frames. Resource constraints, mainly financial, human capital and technological barriers, hinder the product development process. In addition, the industry specific policy and infrastructure limitations made the burden on it. Statement on the support of other departments and employees on manager's product development attempt received neutral mean scores. Furthermore, mangers of established firms with large number of product range was highlighted that they were receiving strong support on the conversion process and collaboration of all parties were high to achieve the targets. Results (Table 04 and 5) support on conversion of product concepts or ideas into practise and Sri Lankan fish and seafood processing firms can be categorised as conversion moderate group.

Table 05: Measurement of idea/product development

\begin{tabular}{lcc}
\hline \multicolumn{1}{c}{ Statement } & Mean & Std. Deviation \\
\hline $\begin{array}{l}\text { 9. New product development projects often don't } \\
\text { finish on time }\end{array}$ & 2.84 & 0.36 \\
$\begin{array}{l}\text { 10. Mangers receive lots of support in } \\
\text { developing new ideas }\end{array}$ & 3.96 & 0.19 \\
\hline
\end{tabular}

The final three statements in Hansen and Birkinshaw's capability measure were targeted to identify the firm's capacity on diffusion of product idea. Results (Table 06) revealed that processing firms were behaving neutrally on diffusion of ideas. They were reluctant to say that they were slow to roll out new products and competitors' attitude on their work. But the majority agreed that they were not penetrating all possible markets and channels, and not catering to wider market segments. Nelson and winter (1982) states that external sources of variety allow firms to create new combinations of technologies and knowledge. The product development process is itself a form of problem-solving activity and associated search processes involve in investments in building and sustaining links with users, suppliers, and wide range of different institutions inside the innovation system (Hippel,1998). 
Table 06: Measurement of idea/product concept diffusion

\begin{tabular}{lcc}
\hline \multicolumn{1}{c}{ Statement } & Mean & Std. Deviation \\
\hline $\begin{array}{l}\text { 11.We are slow to roll out new products } \\
\begin{array}{l}\text { 12. Competitors are slow to copy our product } \\
\text { introductions }\end{array}\end{array}$ & 3.30 & 0.97 \\
$\begin{array}{l}\text { 13. We don't penetrate all possible channels, } \\
\text { customer groups and regions with new products } \\
\text { and services }\end{array}$ & 3.92 & 0.93 \\
\hline
\end{tabular}

The open innovation capability of the firms is presented in Table 07 . Processors disagreed with the statements that they were having few collaborative innovation projects with consumers, retailers and suppliers. Especially, they were managing collaborative initiatives with foreign retailers, retail chains, consumers and suppliers on idea generation and sustainability of the resources. Moreover, they have shown neutral responses on their collaborations with traders, wholesalers, sales promotions and advertising personals. Results revealed that their new product development incorporates the ideas of value chain members.

Table 07: Measurement of open innovation capability

\begin{tabular}{lcc}
\hline \multicolumn{1}{c}{ Statement } & Mean & Std. Deviation \\
\hline $\begin{array}{l}\text { 14. Few of our projects involve with external } \\
\text { members (consumers) of the company }\end{array}$ & 2.65 & 1.01 \\
$\begin{array}{l}\text { 15. Few of our projects involve with external } \\
\text { members (suppliers) of the company }\end{array}$ & 2.53 & 0.90 \\
$\begin{array}{l}\text { 16. Few of our projects involve with external } \\
\text { members (retailers) of the company }\end{array}$ & 2.50 & 0.94 \\
$\begin{array}{l}\text { 17. Few of our projects involve with external } \\
\text { members (traders and wholesalers) of the } \\
\text { company }\end{array}$ & 3.00 & 1.01 \\
$\begin{array}{l}\text { 18. We are well connected with sales promotions/ } \\
\text { advertising/media personnel }\end{array}$ & 3.23 & 0.86 \\
$\begin{array}{l}\text { 19.We have open window to get ideas from } \\
\text { outsiders }\end{array}$ & 3.76 & 0.71 \\
$\begin{array}{l}\text { 20.Our new product development incorporate } \\
\text { ideas of value chain members }\end{array}$ & 4.30 & 0.47 \\
\hline
\end{tabular}

Sustaining fishery resources is of paramount importance and the industry entirely depends on availability of the resources. The Sri Lankan fish and seafood processing industry is catering mainly to the EU, the USA and Japan, and their commitment to international market regulations was given higher priority. Results revealed their agreement to ensure sustainability in the 
production process and response to international market regulations (table 8). Table 08: Measurement of commitment on sustainability

\begin{tabular}{lcc}
\hline \multicolumn{1}{c}{ Statement } & Mean & Std. Deviation \\
\hline $\begin{array}{l}\text { 21. We are committed to produce sustainable } \\
\text { products }\end{array}$ & 4.34 & 0.48 \\
$\begin{array}{l}\text { 22.We are always follow international market } \\
\text { regulations and certifications }\end{array}$ & 4.46 & 0.50 \\
\hline
\end{tabular}

Measuring the relationship between open innovation and firm performance is the principal target of this study. Performance of the export processing firms was measured using two indicators, product and market achievements of the considered period. Results of the firm performance (products and markets) and open innovation are described in table $9(9.1,9.2,10.3)$ and $10(10.1$, $10.2,10.3)$. The results reject the null hypothesis in favour of the alternative, indicating a significant relationship between firm performance and open innovation. Open innovation activities help to develop a wide range of new products and product lines, introducing new species, processing techniques, packaging materials, adapting to international market requirements, customer relations, new market entry and cater for different market segments. Moreover, exposure to open innovation leads to build the capacity in human, physical and financial resources.

Table 09.1: Firms performance (Products) - Paired Samples Statistics

\begin{tabular}{llcccc}
\hline & Mean & N & $\begin{array}{c}\text { Std. } \\
\text { Deviation }\end{array}$ & $\begin{array}{c}\text { Std. Error } \\
\text { Mean }\end{array}$ \\
\hline \multirow{2}{*}{ Pair 1 } & Products post \& & 11.6923 & 26 & 6.85139 & 1.34367 \\
& pre open innovation & & 26 & .47068 & .09231 \\
\hline
\end{tabular}

Table 09.2: Paired Samples Correlations

\begin{tabular}{llccc}
\hline & N & Correlation & Sig. \\
\hline Pair 1 & $\begin{array}{l}\text { Products post \& pre open } \\
\text { innovation }\end{array}$ & 26 & .440 & .025 \\
\hline
\end{tabular}

Table 09.3: Paired Samples Test

\begin{tabular}{|c|c|c|c|c|c|c|c|c|}
\hline \multicolumn{9}{|c|}{ Paired Differences } \\
\hline & \multirow{2}{*}{ Mean } & \multirow{2}{*}{$\begin{array}{c}\text { Std. } \\
\text { Deviation }\end{array}$} & \multirow{2}{*}{$\begin{array}{c}\text { Std. Error } \\
\text { Mean }\end{array}$} & \multicolumn{2}{|c|}{$\begin{array}{c}95 \% \text { Confidence Interval } \\
\text { of the Difference }\end{array}$} & \multirow[t]{2}{*}{$\mathrm{t}$} & \multirow[t]{2}{*}{ df } & \multirow[t]{2}{*}{$\begin{array}{c}\text { Sig. } \\
\text { (2-tailed) }\end{array}$} \\
\hline & & & & Lower & Upper & & & \\
\hline Products Post & & & & & & & & \\
\hline $\begin{array}{c}\text { Pair } 1 \text { and pre open } \\
\text { innovation }\end{array}$ & 7.38462 & 6.65779 & 1.30570 & 4.69548 & 10.07375 & 5.656 & 25 & .000 \\
\hline
\end{tabular}


Results revealed that firm performance based on products has significant relationship with its open innovation activities. Nature of the Sri Lankan export processing firms highlighted that R \& D facilities were poor for innovative product development activities. External sourcing of ideas facilitates them to improve their innovativeness and results proved the link between external sourcing of ideas and firm performance. Especially external sourcing of ideas and its relationship with the performance provides solutions for the resource poor firms to achieve success. Developing nations holding the lion's share of the international fish and seafood trade but most of the processing firms rarely allocate resources for research and development. In one hand ever changing consumer tastes, preferences, legal and regulatory changes requesting the processors to rethink their products. On the other hand survival of the processing firms in international market depends on their adjustments to dynamic market requirement. Present findings show the promising direction to the fish and seafood processing firms to perform well in international market with diversified product range.

Table 10.1: Firms performance (markets) - paired samples statistics

\begin{tabular}{llcccc}
\hline & Mean & $\mathrm{N}$ & $\begin{array}{c}\text { Std. } \\
\text { Deviation }\end{array}$ & $\begin{array}{c}\text { Std. Error } \\
\text { Mean }\end{array}$ \\
\hline \multirow{2}{*}{ Pair 1 } & Markets post \& & 6.8846 & 26 & 3.05060 & .59827 \\
& Pre open innovation & 4.3077 & 26 & .47068 & .09231 \\
\hline
\end{tabular}

Table 10.2: Paired samples correlations

\begin{tabular}{lllcc}
\hline & & N & Correlation & Sig. \\
\hline Pair 1 & Markets pre \& post open innovation & 26 & .499 & .009 \\
\hline
\end{tabular}

Table 10.3: Paired sample test

\begin{tabular}{|c|c|c|c|c|c|c|c|}
\hline \multirow{3}{*}{ Mean } & \multicolumn{4}{|c|}{ Paired Differences } & \multirow{3}{*}{$\mathrm{t}$} & & \multirow{3}{*}{$\begin{array}{c}\text { Sig. } \\
\text { (2-tailed) }\end{array}$} \\
\hline & \multirow[t]{2}{*}{$\begin{array}{c}\text { Std. } \\
\text { Deviation }\end{array}$} & \multirow[t]{2}{*}{$\begin{array}{l}\text { Std. Error } \\
\text { Mean }\end{array}$} & \multicolumn{2}{|c|}{$\begin{array}{l}95 \% \text { Confidence } \\
\text { Interval of the } \\
\text { Difference }\end{array}$} & & df & \\
\hline & & & Lower & Upper & & & \\
\hline
\end{tabular}

No. of markets

$\begin{array}{llllllll}\text { Pair } 1 \text { post \& pre open } 2.57692 & 2.84497 & .55794 & 1.42782 & 3.72603 & 4.619 & 25 & .000\end{array}$ innovation

Role of markets is identifying appropriate marketing channels where their inventions will pay off with promising returns (Bratvold, 2014). Content creation remains with a huge undertaking of opportunity costs. But if firms resources and $\mathrm{R} \& \mathrm{D}$ budget are stretched to limit or unavailable, what else might firm has to do? Study has proved that crowd sourcing will facilitate 
the creation of opportunity cost as well as content marketing where firm can secure returns. Further, crowd sourcing speed the process of market content creation, links existing as well as potential customers, encourage your target audience to invest in the process, and offers diversity and creativeness.

\section{Conclusion}

The research focused on the fish and seafood export industry of Sri Lanka which was aimed to investigate the nature of open innovation practices among fish and seafood exporters, find the role of open innovation on product and process development, market identification, market expansion, brand image, quality control, labelling and certification, sales promotion and advertising, and sustainability of the resources and find the relationship between open innovation and firm performance.

Sri Lankan processors mostly deal with three species namely tuna, swordfish and shrimp, mainly exported to the EU, the USA and Japanese markets. Product lines include fresh, semi processed, ready to cook, and ready to eat and an increasing trend was observed in value addition. Moreover, firms' commitment to international market regulations was great and all of the firms maintain HACCP, and EU certification and traceability system for products. However, none of the firms have their own R\&D department and firms rarely allocate designated persons to the work of $R \& D$. The mean result for $R \& D$ allocation of the firms was $4.61 \%$ and some of the firms do not allocate a separate R\&D budget. Firms which do not maintain separate budgets for R\&D were directing funds for the product and process development whenever the necessity occurs. The majority of the firms were lacking a separate R\&D department, and a full time leader on product and process development. The common feature was top level managers and quality control heads were dedicated on innovation process and acting as a leader.

Open innovation practices of the processing firms were identified in three main categories, namely idea generation, product development and marketing. First, open innovation enhances the firm's idea generation and information search functions. Second, the product development phase was critical to Sri Lankan processors, like most of other developing nations, with investment barriers. Government institutions involved in facilitating the process while external sources or crowds playing great role behind the product development process. Third, marketing has great importance to the process and firms dealing directly with foreign retail chains manage the entire marketing process with fewer burdens to the firms.

Study proves that processing firms were idea rich and were positively collaborated internally for innovative projects. Firms were behaving moderately on conversion of innovative ideas into products. The study reveals that lots 
of innovative ideas cease in the investment planning and poor screening or validation process. Resource constraints lag plans behind or made firms more risk averse. Firms were behaving neutrally on diffusion of product ideas. Human resources limitations made poor availability of strategic marketing plans. Therefore, novel product ideas were not converted into final products and could not reach into the final market. Healthy relationships were observed with firm's value chain participants. Moreover, firms were highly dedicated on sustainability of the resources, especially the oceans with positive response to international market regulations.

Prime objective of the study was to investigate the relationship between firm performance and open innovation. Firm performance, both products and markets, have significant relationship with open innovation. Fish and seafood value chains no longer exist fully within one company, country or region. The value chain begins with producers beyond the national boundaries and caters to geographically diverse markets. Therefore, collaboration of different people and their ideas can create economic value through intellectual property. Moreover, healthy collaboration will act favourably on sustainability of the oceans and other resources. Especially, the country's education should generate the best human resources and close the gap between industry and academia. Thus, there is an urgent need to actively reach out to universities and research institutions to bring out the best knowledge and technology. Idea of crowd sourcing has merged with other ways to create new business dimensions for the fish and seafood export processing industry.

\section{References}

Chesbrough, H.W. (2003), Open Innovation: The New Imperative for Creating and Profiting from Technology, Harvard Business School Press. DOI: http://dx.doi.org/10.1108/14601060410565074

Bratovld, D. (2014). Five ways crowd sourcing improves your content marketing, Convenience and Content marketing group, Accessed $25^{\text {th }}$ January 2014. www.convienceandcontent.com

Duke, C.B. (2004). Creating Economic value from research knowledge, The Industrial Physicist, American Institute of Physics pp 29-31

Hippel von Eric (1988), The sources of innovation, Oxford University Press, Accessed 28 ${ }^{\text {th }}$ December 2011. http://ideas.repec.org/a/eee/respol/ v18y1989i5p297-297.

Food and Agriculture Organisation (FAO). (2010). The state of world fisheries and Aquaculture - 2010, FAO Fisheries and Aquaculture Department, FAO, Rome, Italy. Pp 3-11. DOI: http://dx.doi.org/10.1080/03632415.2 014.966265 
Grehalva R. (2004). Un leasing the power of consultative selling, P2P people to people communications media

Hall A. (2010). Integrating internal and external resources: open innovation, absorptive capacity and integration approaches, Accessed $5^{\text {th }}$ November 2010 from http://edu.cengage.co.uk/images/SChapter-1408019221.pdf

Hansen M. T. And Birkinshaw J. (2007). The innovation value chain, Harvard Business Review, Accessed 15 ${ }^{\text {th }}$ October 2011 from https://blog.itu.dk/ KMP-E2008/files/2008/08/theinnovationvaluechain.pdf

Laursen K. And A. Salter. (2006). Open for innovation: the role of openness in explaining innovation performance among U.K. manufacturing firms, Strategic Management Journal, Vol.27. pp 131-150. DOI: http://dx.doi. org/10.1002/smj.507

Nationmaster. (2008). Global innovation index, Accessed 10 ${ }^{\text {th }}$ December 2011 from http://www.nationmaster.com/graph/eco_inn-economy-innovation

Nelson R. And S. Winter (1982). An Evolutionary Theory of Economic Charge, Belknap Press of Harvard University Press: Cambridge MA. DOI: http://dx.doi.org/10.1017/s0022050700046106

Sarkar S. And Ana I.A. Costa. (2008). Dynamics of open innovation in the food industry, Trends in Food Science and Technology, Vol.19 pp 574580. DOI: http://dx.doi.org/10.1016/j.tifs.2008.09.006

UNICEF (United Nations International Children's Emergency Fund) . (2010). Sri Lanka, Statistics. Accessed 15 ${ }^{\text {th }}$ December 2011 from http://www. unicef.org/infobycountry/sri_lanka_statistics.html 